\title{
視覚障害と脳の代謝パターンの関連について
}

\author{
清 澤 源 弘
}

（東北大学医学部眼科学教室）

\section{Correlationship Between Visual Impairments and Cerebral Metabolism Patterms}

\author{
Motohiro Kiyosawa, M. D.
}

(Department of Ophthalmology, Tohoku University School of Medicine)

\section{I はじめに}

通常人間の視覚に伴う脳の活動を測定するの には視覚誘発電位が用いられている。殊に立体 トポグラフィー脳波は臨床的にも解り易いが, 定位置性と定量性に欠点が残る。脳が活動する 時のエネルギーとして利用されるグルコースの 消費量を放射線を用いて臨床的に測定する方法 がポジトロンエミッショントモグラフィー（P E T）のF D G 法である。本法は定位性と定量 性にすぐれていて人間の脳が物をどうやって見 ているかを教えてくれる。

サイクロトロンにより作られるフッ素18を用 いてF D Gが合成される。F D Gは人体投与の 為の品質検査の後に静注される。F D G は血液 中のグルコースと共に脳に取り込まれて解糖系 の流れに入り糖消費の盛んな所に蓄積される。 ここでF D Gの中のフッ素18はポジトロンを出 し, 更にこのポジトロンが体内で $\gamma$ 線に変わっ たものを C Tスキャン様の P E T で測定する。
この測定にかかる時間は約60分である。正確な 定量には動脈採血の併用が望ましい。本報では おもに我々のデータを用いて，この方法による 視覚に伴う脳のブドウ糖代謝の変化を説明する。

\section{II 視路の概要}

光は網膜にて神経興奮に変換され, 網膜上で の処理を受けたのち視神経, 視交叉, 視索を経 て外側膝状体へと伝わる。視交叉前の障害が片 眼の視力低下を，また視交叉後の障害が同名半 盲をきたすことはよく知られている。外側膝状 体のシナプスをこえて, 視覚情報は側脳室の脇 を回る視放線を経て第一次視覚領（有線領皮 質）に至る。この第一次視覚領は後頭葉内側に あり，視野を左右，上下を逆にして更に後頭葉 の先端が視野の中心に来る様に配置した形をし ている。この第一次視覚領は後頭葉外側面の連 合領に神経線維を送っていて, これが視覚連合 領とよばれるものである。

\section{連絡先（９980）仙台市青葉区星陵町 $1-1$ \\ 東北大学医学部眼科学教室}

Key Words: Positron Emission Tomography,

PET, Cerebral metabolism,

$\mathrm{V}$ is ion 


\section{III 視覚刺激と脳代謝}

通常人間は特に注意していなくても開瞼して いれば何かを見ている。このときの眼からの脳 へのインパルスは, 安静閉瞼状態の“流れ”と 視覚情報の“流れ”の合わさったものになるだ ろう。これらの関係を検討するには，まず両眼 を閉じてみるとよい。P E T画像をながめても わからない位の差だが, 定量してみると後頭葉 内側の第一次視覚領に約 $14 \%$ の低下がおきてい ることがわかる11。

次に光刺激だが，パターンリバーサルのチェ ッカーボード刺激はその頻度やサイズによって 異なった刺激を脳に与えることが知られている。 またパターンリバーサルは脳の高次機能に関係 する様な情報を含まないという特徴を持つ。 Kushnerの実験ではこのパターンリバーサル刺 激による脳の賦活効果は約15\%位のものである ことがわかっだ2。

日常生活において我々が目を使うという作業 をする時，例えば読書をする時，目より入った 情報は次々に視覚連合領へと伝わり分析さ扎て ゆく。だから読書時の P E T は脳の糖代謝の増 加が第一次視中枢に限らず視覚連合領にも広が っていることを示す ${ }^{3)}$ 。 最大ではこの賦活効 果は第一次視覚領でも視覚連合領でも安静時の $50 \%$ になる。

\section{IV 視覚障害と脳代謝}

最も明らかな失明状態は両眼性の視神経障害 でみとめられる。殊に発症してから間もない成 人の両側視神経障害では本来脳に入るべき安静 時の目からのインパルスまで止まってしまうの で, 脳の後方半分を切り落とした様な第一次視 覚領, 視覚連合領に広がる広範な代謝低下を示 す (図 1)。両眼性緑内障なども同様である ${ }^{1)} 。$ 一方, 生後すぐに視力を失った人では, 両眼 性の失明者でもほぼ正常の後頭葉代謝を示すこ とが知られている ${ }^{4)}$ 5)。これについては，視覚 の発達に伴いシナプスが増加し, 更にこれが選 択的にけずられることで正常な視覚が形成され てゆくという正常な経過をへていないことがそ の原因だと説明されている。

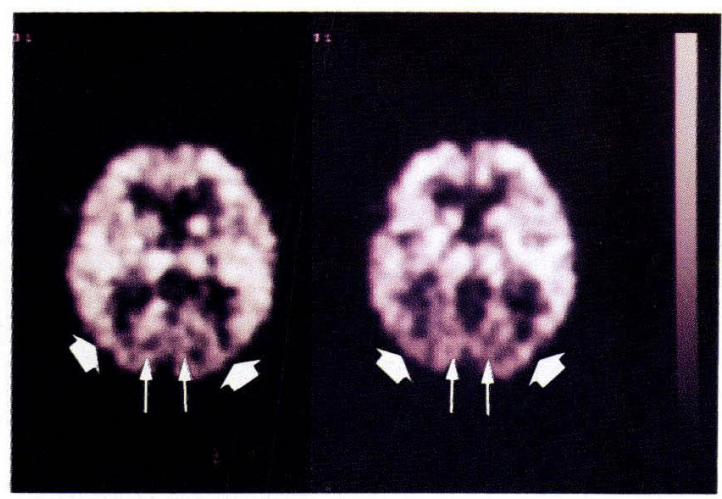

困 1 : 両眼視神経障害者の脳糖代謝

両側性虚血性視神経症では第一次視覚領 (小矢印) 及び視覚連合領 (大矢印) を含む広範な後頭葉の糖 代謝低下が認められる。

弱視についてはどうであろうか？ 弱視を対 象とした Demer の研究により明らかなことは, 良い眼を刺激した方が弱視眼の刺激をした時よ りも視覚領はよりよく働くということだけであ る ${ }^{6)}$ 。より詳しい研究がまたれる所であろう。

半盲は視路の障害により両眼で視野の半分が 失われる状態であるが, 同名性半盲では片側の 第一次視覚領が働きを失う。この結果チェッカ ーボードで両眼に全視野刺激をした時の陳旧例 では, 健常半球の視覚領皮質の代謝の増加と, 傷害側半球での代謝の低下が重なり, この時の 左右不対象は約 $22 \%$ になった

しかし, 半盲の原因が発症したばかりの脳梗 塞となると状況は変わる。脳はそれぞれの部位 が，互いに信号を送り合って全体としての緊張 を保っているので, 視野に欠損をおこす程度の 中大脳動脈の梗塞などがおきると脳全体の活動 が弱くなってしまう。時には意識水準の低下な どの形をとるが, 発症初期の中大脳動脈梗塞例 での後頭葉の糖代謝は正常人に比べると患側で 70\%の低下，対側でも60\%もの低下を示した ${ }^{7) 。 ~}$ 最後に示すのは, 高次視覚障害とよばれるも のである。代表的なものが視覚障害を伴うアル ツハイマー病であって, 臨床症状としては, 原 
因のはっきりしない読書困難, 自分のいる環境

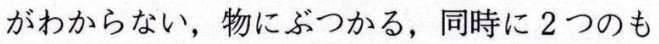
のが認識できないなどと訴える。臨床検査では, 二重五角形の転写不能, 石原式色覚検査の不能, 及びチトマス立体視試験での立体視の欠如が認 められる(図 2)。

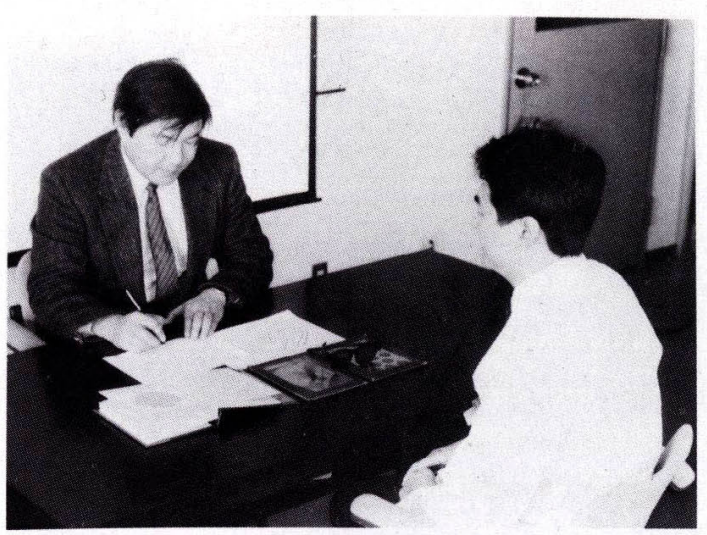

図 2 : アルツハイマー病検査に有用な諸検査用具 二重五角形転写検査, 石原式色覚検査及びチトマス 立体視試験はいずれも簡単な検査であるが, 視覚症 状を伴うアルツハイマー病の検出には非常に有用で ある。

しかし視力ゃ, 視野自体は保たれているので ある。この患者に特有な脳糖代謝の低下は視覚 連合領から角回にかけてであって，視覚に伴う 認識が特異的におかされるという本疾患の特 徵をよく示している ${ }^{8)}$ (図 3 )。最近の報告で は視路のうちの動きや深度覚に関連する部分 (Magnocellular system) が本疾患では特に傷害さ れるという説も提出されている。

これらの関係をグラフにしたのが図 4 である。 横軸に第一次視覚領をとり檤軸に視覚連合領を とった。脳の代謝はほぼ45度の線上にあるが， アルツハイマー病ではその線から外れている91。

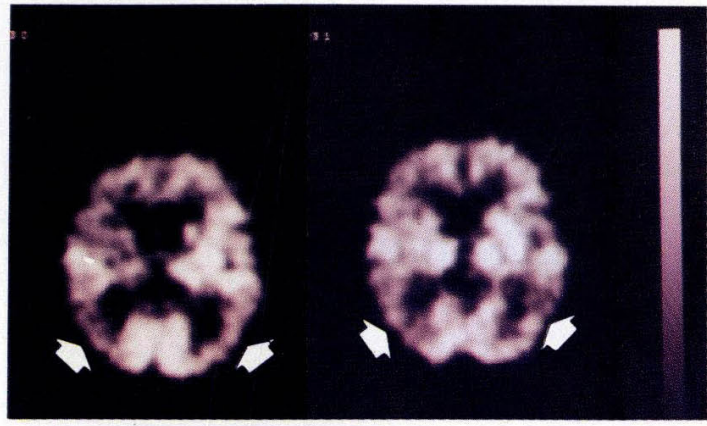

図 3：アルツハイマー病の脳糖代謝

典型的な視覚障害を伴うアルッハイマー病患者の 脳代謝は視覚連合領が特異的に欠落する（矢印）。

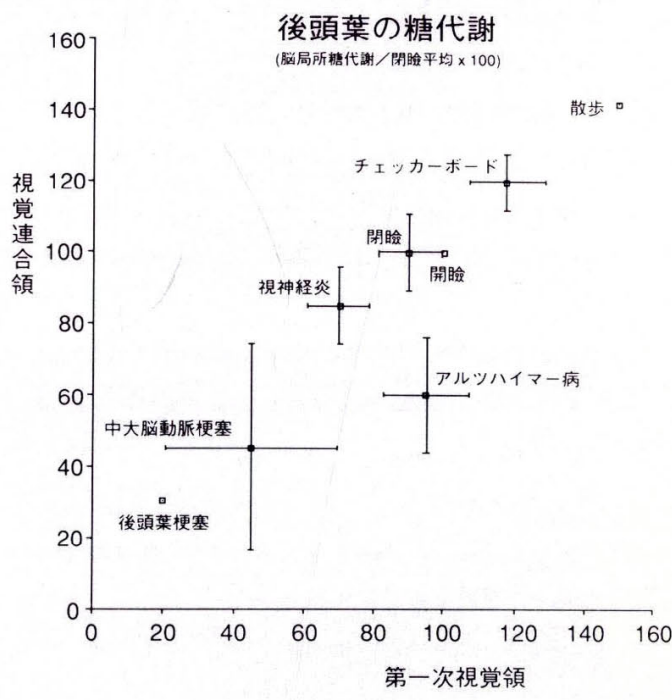

図 4 : 様々な刺激や病態による後頭葉糖代謝 基本的には視覚連合領の代謝は第一次視覚領の代 謝に依存しているので正の相関を示している(文献 $1,2,3,7,8$ より作成。文献 9 より引用)。 


\section{V まとめ}

ポジトロン断層法によって, 視覚刺激や視覚 障害に伴う人間の脳の代謝の変化がわかる。主 な変化は後頭葉視覚領にあらわれるが，その刺 激や障害によってはより広範な変化が認められ る。それは, 大脳視覚領が単に感覚としての受 容の終点ではなく, 脳内情報処理や行動への始 点でもあることを示している。ポジトロン断層 法は未だ特殊な検査であるが, 今後視覚生理学 上の問題の解明や臨床への幅広い応用が期待さ れる。

稿を終えるにあたり，P E T の施行に協力いた だいた東北大学サイクロトロン R I センター各位, 眼科中川陽一先生, 老人科目黒謙一先生に深謝い たします。

\section{参考文献}

1) Kiyosawa M, Bosley TM, Kushner M. et al.: Positron emission tomography to study the effect of the eye closure and optic nerve damage on human cerebral glucose metabolism. Am. J. Ophthalmol. 108 : 147$152,1989$.

2) Kushner MJ, Rosenquist A, Alavi A, et al. : Cerebral metabolism and patterned visual stimulation: a positron emission tomographic study of the human visual cortex. Neurology: $38: 89-95,1988$.

3 ) Kiyosawa M, Mizuno K, Hatazawa J, et al. : Metabolic imaging in hemianopsia using positron emission tomography with $18 \mathrm{~F}$ deoxyglucose. Am. J. Ophthalmol. $101: 310$ - 319, 1986.

4 ) Bosley TM, Kiyosawa M, Moster M, et al. Neuro - imaging and positron emission tomography of congenital homonymous hemianopia. Am. J. Ophthalmol. $111: 413$ 418, 1991.

5 ) Varaart C. Devolder AG, Wanet - Defaque $\mathrm{MC}$, et al. Glucose utilization in human visual cortex is abnormally elevated in blindness of early onsent but decreased inb lindness of late onset. : Brain res. 510 : $115-121$, 1990.

6 ) Demer JL, Von Noorden GK, Volkow ND, Goukd L. : Imaging of cerebral blood flow and metabolism in amblyopia by positron emission tomography. Am. J. Ophthalmol. 105: $337-347,1988$.

7 ) Kiyosawa M, Bosley TM, Kushner M. et al. Middle cerebral artery strokes causing homonymous hemianopia : positron emis sion tomography. : Ann Neurol 28 : 180 183, 1990.

8) Kiyosawa M, Bosley TM, Chawluk J. Jamieson D, et al. : Alzheimer's disease with prominent visual symptoms, Clinical and metaboic evaluation. Ophthalmolgy 96 : 1077 - 1096, 1989.

9 ) 清澤源弘, 中川陽一 : 脳循環代謝之視覚, 眼 科34: 559-566, 1992. 